\title{
CONFERENCE OF BALTIC UNIVERSITIES (CBUR)
}

Lunds universitet

Box 117

22100 Lund (Sweden)

1990

Tel: (46) 107001

Fax: (46) 46104436

Telex: lunivers s 33533

Chairman: Prof. Michael Müller-Wille,

Rector, University of Kiel

Secretary: Bengt Nilsson

An independent, non-governmental organization with membership open to all universities and equivalent institutions with full academic rights in the Baltic area. Its aims are the promotion of interuniversity cooperation throughout the Baltic area, to support research undertakings, share didactic experience and widen mutual contact of academic staff and students. Within the scope of the Conference's interests are branches of science and all those branches of the humantities which could help to understand better traditions, customs, mentalities, as well as laws and public institutions.

La Conférence des universités baltes (CBUR) est une organisation non gouvernementale, indépendante, dont l'affiliation est ouverte à toutes les universités et institutions équivalentes jouissant des pleins droits académiques dans la région balte. Elle a pour objectifs: de promouvoir la coopération interuniversitaire, d'apporter son soutien aux initiatives de recherche et d'élargir les contacts entre professeurs et étudiants. Figurent parmi les centres d'intérêt de la Conférence les branches scientifiques et toutes celles des humanités susceptibles d'aider à mieux comprendre les traditions, les coutumes, les mentalités, ainsi que les lois et les institutions publiques. 